\section{Tatiana Belemets, Irina Radzievskaya, Oksana Tochkova, Nataliia Yushchenko, Uliana Kuzmyk, Artur Mykhalevych}

\title{
EVALUATION OF OXIDITY RESISTANCE OF MILK-CONTAINING PRODUCTS BASED ON BLENDING OF VEGETABLE OILS
}

It is known that one of the main causes of spoilage of fats (in particular vegetable fats), as well as products made with their use, is an increase in acid and peroxide numbers. Physicochemical indicators have a significant impact not only on the quality and organoleptic characteristics of the product, but also on its safety. For this purpose, the dependence of the indicators of acid and peroxide numbers of the created blend of vegetable oils in the technologies of milk-containing products during storage has been investigated. The object of research is experimental samples of a three-component blend of vegetable oils and milk fat isolated from milk-containing curd paste and milk-containing sour cream sauce. The subject of research is the dynamics of the growth of acid and peroxide numbers of samples and changes in their organoleptic quality indicators.

The obtained data on the kinetics of oxidation of a blend of vegetable oils indicate that the increase in acid and peroxide numbers during the studied shelf life does not differ in intensity. The average threshold for an increase in acid and peroxide numbers is insignificant and amounts to $0.02-0.03 \mathrm{mgKOH} / \mathrm{h}$ and $0.2-0.21 \mathrm{mmol1} / 2 \mathrm{O} / \mathrm{kg}$ for 5 days. In accordance with the obtained results of the kinetics of oxidation of the released fat of milk-containing curd paste, there is a slight increase in acid and peroxide numbers, namely: at the end of 7 days - up to $0.3 \mathrm{mgKOH} / \mathrm{h}$ and $1.9 \mathrm{mmol1} / 2 \mathrm{O} / \mathrm{kg}$, respectively, and in at the end of 10 days - up to $0.32 \mathrm{mgKOH} / \mathrm{h}$ and $2.3 \mathrm{mmol1} / 2 \mathrm{O} / \mathrm{kg}$. Based on the obtained results of the kinetics of oxidation of the released fat from the milk-containing sour cream sauce, there is a tendency to a gradual increase in the acid and peroxide numbers with an increase in the oxidation time. It is noted that the maximum values of acidic $-0.3 \mathrm{mgKOH} / \mathrm{h}$ and peroxide numbers $-2.2 \mathrm{mmol1} / 2 \mathrm{O} / \mathrm{kg}$ at the end of the shelf life of 21 days are reached. According to the results obtained for the organoleptic evaluation of experimental samples of the blend and the released fat from milk-containing products, no significant changes were found during the studied shelf life.

Keywords: milk-containing curd paste, milk-containing sour cream sauce, blend of vegetable oils, acid number, peroxide number.

\section{Introduction}

Today, nutrition is considered not only from the point of view of an energy source, but also as a way to prevent diseases. At the same time, it is worth noting the current living conditions, which became the reasons for changes and loss of some enzyme systems responsible for the endogenous synthesis of a part of the class of essential nutrients, as well as a decrease (with age) in the body's ability to synthesize vitamins and the general bioavailability of nutrients from foods for power supply [1]. Even with a balanced and complete daily diet, some external factors (transfer of infectious diseases, stress, taking certain medications, impaired absorption of the gastrointestinal tract) can lead to a deficiency of nutrients and essential fatty acids (FA) in particular [2]. In this regard, the need arose in the food industry to create a new class - functional food products. The most expedient for meeting this goal is the use of vegetable oils as an enriching component and sources of essential FAs in the technologies of products that are recommended by nutritionists for daily consumption, namely, fermented milk products.

The trend of increasing interest in the use of vegetable oils in the food industry is explained by the fact that vegetable lipids are products of constantly renewable raw materials that can be easily obtained in almost any country with various biological resources. It is plant lipid complexes that contain biologically active substances (BAS) carotenoids, tocopherols, phospho- and glycolipids and phytosterols. This variability of valuable BAS allows to consider vegetable oils as not only independent drugs, but also as promising sources for the manufacture of functional products for preventive action [3]. However, none of the existing vegetable oils on the market independently has a native optimal fatty acid and acylglycerol composition and a sufficiently wide range of biologically active substances. This problem can be solved and a fat component with a hypothetically ideal FA composition can be obtained through the implementation of the blending process [4]. It is worth noting that, for example, in Ukraine, the culture 
of consumption of these products has not yet been fully formed. At the same time, the economic efficiency, simplicity of the technology for producing blends and the balance of the composition - bring their use to the category of relevant and promising [5].

\section{The object of research and its technological audit}

The object of research is experimental samples of a threecomponent blend of vegetable oils and milk fat isolated from milk-containing curd paste and milk-containing sour cream sauce.

The subject of research is the dynamics of growth of acid and peroxide numbers of selected experimental samples and changes in their organoleptic quality indicators.

It should be noted that vegetable oils in the composition of the developed blend are characterized by a rather high content of tocopherols, especially walnut oil (Table 1), which will contribute to the stability of the fat phase of new types of milk-containing products with their use [6].

Table 1

Content of tocopherols and their isomers in blend oils

\begin{tabular}{|c|c|c|c|c|}
\hline \multirow{2}{*}{ Type of oil } & \multirow{2}{*}{ Total content, mg \% } & \multicolumn{3}{|c|}{ Isamers, \% total } \\
\cline { 3 - 5 } & & $\alpha$ & $\beta$ & $\gamma+\delta$ \\
\hline Rapeseed & 56 & 27 & 73 & - \\
\hline Corn & 655 & 49.1 & 42.4 & 8.5 \\
\hline Walnut & 109 & 46.4 & 48.0 & 5.6 \\
\hline
\end{tabular}

So, vegetable oils and blends based on them have different physicochemical characteristics, nutritional value, as well as stability during storage. That is why an important task for scientists is to find ways to increase the stability of vegetable oils for the possibility of their use in functional food technologies.

Guided by the above arguments, the authors of the work previously developed a blend based on natural vegetable oils, which included: corn and rapeseed oils, and walnut oil. The amount and ratio of each oil was calculated in advance using a specially created mathematical program in the MATLAB package [7]. The specificity of the choice of components for blending is substantiated by the native fatty acid composition of milk fat, natural vegetable oils, as well as their beneficial properties.

In this case, the ratios of linolenic and linoleic acids $(\omega-6: \omega-3)$ were taken into account: for healthy people 10:1, for elderly people and with existing diseases (for example, cardiovascular diseases) - 6-8:1. In this case, the ratio of groups of saturated fatty acids (SFA): monounsaturated fatty acids (MUFA): polyunsaturated fatty acids (PUFA) for a hypothetically ideal fat should be 1:1:1 [8].

Taking into account the aspect of using the developed blend in such technologies of functional products (to replace $50 \%$ of the share of milk fat) such as milk-containing curd paste and milk-containing sour cream sauce, the issue of their oxidation is important. That is why changes in their peroxide and acid numbers will be subject to strict control. In this regard, studies of the indicators of the course of oxidation and hydrolytic processes of blending and the mass fraction of fat of these milk-containing products are promising, because they will establish their shelf life.

\section{The aim and objective of research}

The aim of research is to study the stability and shelf life of a blend of vegetable oils and developed milk-containing products (milk-containing curd paste and milk-containing sour cream sauce) with its use (as a $50 \%$ replacement for the mass fraction of milk fat).

To achieve this aim, it is necessary to solve the following objectives:

1. Experimentally investigate the dynamics of increasing the acid and peroxide numbers of the developed blend based on natural vegetable oils and pre-isolated mixtures of vegetable and animal fats from milk-containing curd paste and milk-containing sour cream sauce.

2. Carry out organoleptic studies of experimental samples of a blend of vegetable oils and isolated mixtures of vegetable and animal fats from milk-containing curd paste and milk-containing sour cream sauce.

3. Based on the data obtained from studies of organoleptic indicators and dynamics of changes in acid and peroxide numbers of selected experimental samples, establish the possible timing of their implementation.

\section{Research of existing solutions of the problem}

Naturally, both independently and as components of a blend, vegetable oils during their storage undergo oxidation and hydrolysis processes. As a result, this provokes unwanted changes in the composition (accumulation of free fatty acids) and in many respects worsens their quality (for example, a decrease in the «stability of emulsions» indicator). The biological and organoleptic values of fats are also subject to significant changes [9].

MUFA and PUFA in the composition of vegetable oils are not stable during storage and can have undesirable side effects associated with the activation of lipid peroxidation and polymerization transformations [10]. It is known that peroxides accumulate more intensively in vegetable oil with an increased content of linoleic and linolenic acids and more slowly when the amount of oleic acid increases. These factors also accelerate the formation of aldehydes, which react with thiobarbituric acid (2-thiobarbituric acid) [11]. In this case, the rate of the fat oxidation process is determined by the structure of fatty acids radicals that make up triglycerides, as well as the presence of catalysts (oxygen, temperature, moisture level, storage container) and oxidation inhibitors (antioxidants). This process is accompanied by the formation of activated derivatives of molecular oxygen (or reactive oxygen species), which are involved in the reactions of free radical and oxidized peroxide, which leads to a decrease in the stability of fats [6].

Oil deterioration is accompanied by the formation of primary oxidation products - free peroxide radicals, the further oxidation of which leads to the formation of secondary compounds - aldehydes, ketones, mono- and dicarboxylic acids, keto acids, aldehyde acids, their esters, as well as other substances that are significantly toxic to the original ones. That is, it is oxidative and hydrolytic processes that cause changes in the physicochemical parameters of oils and make them unusable [12].

Literature data indicate that significant changes in the composition, and, consequently, in quality, vegetable oils experience, starting from the type of agrotechnical 
processing and production technology [13]. For example, the presence or absence of a refining process significantly affects the stability of vegetable oils during storage. Thus, unrefined oil has a relatively low peroxide number and contains a fairly large amount of free high molecular weight FA. Along with the refined oil, there will be an increased amount of peroxides, which may indicate the consequences of removing natural antioxidants (phospholipids, tocopherols, carotenoids) at high temperature conditions [14].

According to the studies [15], it was found that changes in the composition and properties of oils can occur at different stages of refining. Moreover, the refining method affects the antioxidant activity and the ability of the oil to bind free radicals. A correlation has been established between the total content of phenolic compounds and carotenoids with the antioxidant activity of palm oil. It was noted that in the process of refining, the antioxidant activity, the total content of phenolic compounds and carotenoids decreased by $80,26-55$ and $99 \%$ (regardless of the refining method). That is, almost any technology for producing vegetable oils leads to an increase in the peroxide value by several times [16]. Moreover, the intensity of the oxidative processes as a result of thermolysis is due to the presence of a significant amount of unsaturated acids in vegetable oils, and as a result of thermolysis, there is a burning out and a decrease in the nutritional value of the oil. Further, its quality deteriorates and the oil becomes unusable [17].

In [18], the optimal temperature conditions for obtaining vegetable oils were established using the example of flaxseed oil and a mixture of flaxseed and mustard oils (in a ratio of 2:1). According to the regimes at a temperature of $45{ }^{\circ} \mathrm{C}$, the process of oxidation of peroxides and the further formation of compounds hazardous to the body do not occur in linseed oil. A lower acid number for a mixture of oils is achieved at a temperature of $-35^{\circ} \mathrm{C}$ (the optimum storage of these oils is $3{ }^{\circ} \mathrm{C}$ ).

A decrease in the biological value of vegetable oils also occurs during their deodorization process. Consequently, the content of carotenoids decreases by $50 \%$, tocopherols by $15-40 \%$, sterols by $10 \%$; the activity of all fat-soluble vitamins decreases. However, this stage is necessary provided the further use of vegetable oils in some food technologies. In addition, at the stage of deodorization, highly toxic substances 3,4-benziperene (content in oils $0.5-15 \mu \mathrm{g} / \mathrm{kg}$ ), OCPs - organochlorine pesticides and some others are removed [19].

The authors of [20] investigated the effect of temperature regimes of deodorization $(180-240 \mathrm{~m})$ as an activator for the oxidation of triacylglycerols and the formation of a polymerization product in vegetable oil (olive oil). That is, the implementation of technological operations for the processing of oils is accompanied by the removal of some of the native antioxidants, vitamins, and phosphatides (lecithin) from them [21].

The analysis of scientific research [22] shows that when oils are obtained by cold pressing $\left(t=50^{\circ} \mathrm{C}\right)$, the natural amount of phospholipids and tocopherols is preserved, which affect the acid and peroxide numbers, keeping them within the normal range for some time. However, the oil yield at these technological parameters is not high, which, in turn, has a detrimental effect on their price [23].

The resulting oxidation products have a detrimental effect on human health and provoke the onset of various diseases caused by the accumulation of oxidation products in cell membranes [24]. The negative effect of thermally oxidized fats on the human body is assessed by the level of high and low density lipids, cholesterol, hemoglobin and lymphocytes in the blood samples of the examined patients [25].

To protect vegetable fats from harmful auto-oxidation processes, manufacturers often resort to the addition of synthetic antioxidants. The most common antioxidants that are used in the oil and fat industry are ascorbyl palmitate (E304), tocopherols (E307, E308, E309), propylgalate (E310), butylhydroxytoluene (E321), BOA butylhydroxyanisole (E320), etc. However, there are a number of scientific studies, however. the aspect of the negative influence of these substances on the human body is revealed [26].

For this reason, in the scientific search for the present, the main place is occupied by the directions of ensuring the stability of vegetable oils without adding additional antioxidant substances, the selection of new types of natural antioxidants and the creation of an «ideal oil» resistant to oxidation processes due to its native composition [27].

Natural antioxidants in vegetable oil are tocopherols, in particular $\alpha$-tocopherol and carotenoids [28]. Vitamin E is one of the strongest natural antioxidants found in vegetable oils. It inhibits and for some time inhibits the processes of fat oxidation (autooxidation). Moreover, the intensity of auto-oxidation of vegetable oils is in direct correlation with the amount of antioxidants (tocopherols) in oils. Thus, the maximum stability of vegetable fat is achieved at a tocopherol concentration of $35-55 \mathrm{mg} / 100 \mathrm{~cm}^{3}$ [29]. It is assumed that the antioxidant effect of vitamin $\mathrm{E}$ is associated with synergism with vitamin A. Together, these vitamins block the development of peroxidation reactions and significantly increase the resistance of oils to it. Moreover, the quantitative content of vitamin $\mathrm{E}$ in vegetable oil depends on the genotype, oiliness and growing conditions of oilseeds [30].

The accompanying substances, which also contribute to the increase in the stability of oils during storage, are phospholipids, carotenoids and tocotrienols [31].

The authors of [32] determined the degree of inhibition by $\alpha$-tocopherol at a concentration of $50 \mu \mathrm{g} / \mathrm{g}$ of the oxidation of vegetable fats (under conditions of accelerated oxidation at a temperature of $60{ }^{\circ} \mathrm{C}$ ). It was found that a high rate of slowing down of oxidation was observed with a triple combination of $\alpha$-tocopherol, $\beta$-carotene and ascorbyl palmitate. It should be noted that the manifestation of the antioxidant effect is noted both with the combination of $\beta$-carotene and ascorbyl palmitate, and with their individual use.

The effect [33] of the antioxidant properties of vitamin E on the shelf life of vegetable oil has been established. The inhibitory effect of tocopherol on the growth of the acid number has been confirmed, which depends on the type of oil and its shelf life. The most effective inhibition is observed during the storage of cytoplasmic oil - 1.5 months (inhibition by 1.5 times), for refined oil -3.5 months (inhibition by 1.3 times).

Thus, the use of vegetable oils with a naturally high content of tocopherols will ensure their stability during storage without the additional introduction of antioxidants, as well as the stability of food products produced using such oils. 


\section{Methods of research}

To prepare experimental samples of milk-containing products - milk-containing curd paste and milk-containing sour cream sauce - let's use:

- pasteurized cow's milk TM «Yahotyn» (Ukraine) with

a mass fraction of fat (m. f. f.) $3.2 \%$ (DSTU 2661:2010);

- ultra-pasteurized cream TM «Yahotyn» with m. f. f.

$15 \%$ (DSTU 7519:2014);

- dry bacterial starter cultures (DVS-cultures) TM «VIVO» (Ukraine);

- «Curd VIVO» (TU U 15.5-3060300036-001:2009);

- «Sour cream» (TU 9223-001-18137828-2015);

- liquid rennet «NATUREN Premium 145»

(ISO 22000:2005);

- food grade calcium chloride $\mathrm{CaCl}_{2} \mathrm{TM} \ll$ Fudix», Russia (STO 39297743-05-2009).

Freeze-dried sea buckthorn powder (for milk-containing curd paste) and a mixture of freeze-dried garlic and green onion powders (for milk-containing sour cream sauce) were added as flavoring fillers to the developed milk-containing products, developed according to the current regulatory documentation in Ukraine.

In the manufacture of the blend, let's use offensively refined and deodorized vegetable oils: corn TM «KAMA», Ukraine (DSTU GOST 8808:2003), rapeseed oil and walnut oil TM «HENRY LAMOTTE Oil», Germany (ISO 9001).

To create a stable emulsion, pasteurized milk whey of TM «Harmony», Ukraine (TU U 43.39) and yolk powder as a natural emulsifier of natural origin - «yolk in powder» TM «Filvarok», Ukraine (TU U 10.08-39319344-003:2015).

An emulsion of vegetable fats for further use in technologies of milk-containing curd paste and milk-containing sour cream sauce was prepared according to a rational ratio of prescription components (established by preliminary scientific research [8]). This ratio will ensure the stability of the fat phase of milk-containing products - a blend of vegetable oils: milk whey: yolk powder ( $3 \%$ of the amount of added blend), as 21:76:3. The formation of a direct oil/water emulsion was carried out at the same optimal temperature of the components - whey and blend $t=40{ }^{\circ} \mathrm{C}$ (the temperature should not differ by more than $5{ }^{\circ} \mathrm{C}$ ), at a laboratory homogenizer speed $V=1500 \mathrm{rpm}$, for $T=5 \mathrm{~min}$.

The finished emulsion was pasteurized at a temperature of $t=60-62{ }^{\circ} \mathrm{C}$ for $T=2-3$ min in a water bath and cooled to a temperature of $t=20-22{ }^{\circ} \mathrm{C}$ for further inclusion in the composition of milk-containing products. Moreover, the replacement of the mass fraction of fat of the developed milk-containing curd paste and milk-containing sour cream sauce were $9 \%$ and $20 \%$, respectively ( $50 \%$ of the total fat of both milk-containing products were vegetable oils introduced in the emulsion).

The implementation of special sample preparation associated with the removal of the fat phase from the developed milk-containing products was carried out in laboratory conditions according to the following procedure: a weighed portion of the samples of these milk-containing products is ground together with anhydrous sodium sulfate and extracted by the infusion method. For extraction, use the solvents provided for by the appropriate method (when determining the acid number (AN) - hot ethyl alcohol, when determining the peroxide number $(\mathrm{PN})$ - a mixture of isooctane and glacial acetic acid). The resulting fat solution is analyzed according to the titration process described below. Calculation of $\mathrm{AN}$ and $\mathrm{PN}$ is carried out according to the formulas taking into account the fat content in the test sample [34].

To determine the acid number, the method (using hot ethyl alcohol) was used based on the titration (neutralization) of free fatty acids with alkali in the presence of an indicator. According to this method, a sample of research fat (oil) is taken into a conical flask with a capacity of $250 \mathrm{~cm}^{3}$. The weight of the sample is determined depending on the expected value of the acid number (Table 2).

Table 2

The amount of oil weighed in when determining the acid number

\begin{tabular}{|c|c|c|}
\hline Expected OI, mg KOH/g & Sample size, g & Permissible weighing error, g \\
\hline $0.1-1$ & 20 & 0.05 \\
\hline $1-4$ & 10 & 0.02 \\
\hline $4-15$ & 2.5 & 0.01 \\
\hline $15-30$ & 0.5 & 0.001 \\
\hline More than 30 & 0.1 & 0.0002 \\
\hline
\end{tabular}

In the second flask, $50 \mathrm{~cm}^{3}$ of ethyl or isopropyl alcohol containing $0.5 \mathrm{~cm}^{3}$ of phenolphthalein is heated to boiling. For colored oils, the amount of solvent can be increased to $150 \mathrm{~cm}^{3}$. At a temperature of ethyl alcohol above $70{ }^{\circ} \mathrm{C}$, it is carefully neutralized with a solution of potassium hydroxide. Titration is stopped if, upon adding one drop of alkali, a slightly noticeable color change occurs, does not disappear within $15 \mathrm{~s}$.

Pour the neutralized ethanol into the first test flask and mix thoroughly. Bring the contents of the flask to a boil and titrate with a solution of sodium or potassium hydroxide with a concentration of $C=0.1 \mathrm{~mol} / \mathrm{dm}^{3}$ or $C=0.5 \mathrm{~mol} / \mathrm{dm}^{3}$, depending on the expected value of the acid number, thoroughly shaking the contents of the flask during titration.

AN is calculated by the formula:

$$
A N=5.611 \cdot V \cdot K / m
$$

where 5.611 - the titer of $0.1 \mathrm{n}$ potassium hydroxide solution, $\mathrm{mg} / \mathrm{ml} ; V$ - the amount of $0.1 \mathrm{n}$ alkali solution spent on titration, ml; $K$ - correction to the titer of potassium hydroxide solution; $m$ - weight of fat (oil) sample, g.

The used method for determining the peroxide number is based on the interaction of active peroxide or hydroperoxide oxygen with hydriodic acid (HI) in the presence of acetic acid (the method allows determining the PN in the range of values from 0 to $40 \mathrm{mmol} 1 / 2 \mathrm{O} / \mathrm{kg}$ ). According to this method, a $1 \mathrm{~g}$ portion of fat (oil) is weighed into a flask with a ground stopper and $10 \mathrm{~cm}^{3}$ of chloroform is added. Dissolve the sample and add $15 \mathrm{~cm}^{3}$ of acetic acid and $1 \mathrm{~cm}^{3}$ of potassium iodide solution. After that, the flask is closed with a stopper, the contents are stirred for $1 \mathrm{~min}$ and left for $5 \mathrm{~min}$ in a dark place at a temperature of $15-25{ }^{\circ} \mathrm{C}$. Then add $75 \mathrm{~cm}^{3}$ of water, mix thoroughly and add 5 drops of starch solution. The liberated iodine is titrated with $0.01 \mathrm{~N}$ sodium thiosulfate solution. For each test sample, two parallel measurements and a control experiment for the purity of reagents are performed under the same conditions without fat (oil). 
The peroxide number (in millimoles of active oxygen per kilogram of product) is calculated using the formula:

$$
X=\left(V_{1}-V_{0}\right) \cdot C \cdot 1000 / m
$$

where $V_{0}$ - the volume of sodium thiosulfate solution, which was used for titration of the control experiment, $\mathrm{cm}^{3} ; V_{1}-$ the volume of sodium thiosulfate solution, which was used for titration of the main sample, $\mathrm{cm}^{3} ; C$ - concentration of sodium thiosulfate solution, mol $/ \mathrm{dm}^{3} ; m$ - weight of the test sample, g; 1000 - calculated coefficient.

The obtained experimental samples were stored for 21 days for blending and separated fat from milk-containing sour cream sauce for 10 days for separated fat from milkcontaining curd paste (in a cold laboratory chamber at a temperature of $t=+2 \ldots+6{ }^{\circ} \mathrm{C}$, without access to light and air).

The determination of the organoleptic parameters of the experimental samples of the blend and the released fat from milk-containing products was carried out by standard methods in accordance with the current ones.

The obtained results of the organoleptic evaluation of the experimental samples were checked for compliance with the current regulatory standards.

\section{Research results}

6.1. Results of studies of the kinetics of oxidation of a blend of vegetable oils. In order to prove the possibility of using the created blend of vegetable oils in the technologies of milk-containing products (milk-containing curd paste and milk-containing sour cream sauce), the dependence of the acid and peroxide numbers on the selected oxidation period was experimentally investigated. The selected oxidation period is within the guaranteed shelf life of similar products on the Ukrainian market (with the addition of $50 \%$ of the guarantee period).

The obtained results of the kinetics of oxidation of the blend are shown in Fig. 1.

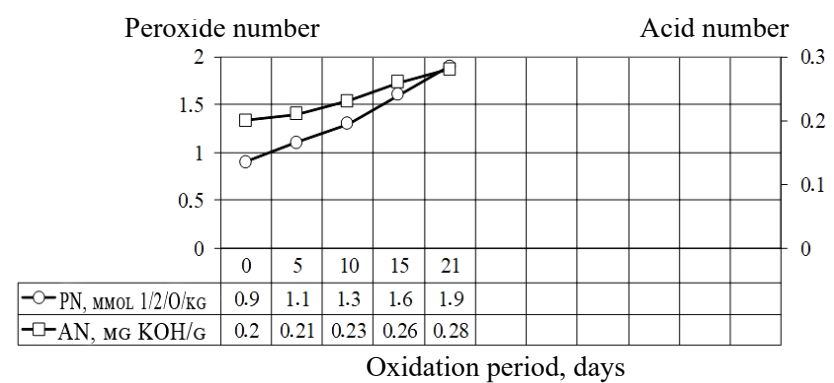

Fig. 1. Study of the kinetics of oxidation of a blend (nut oil $36.62 \%$ rapeseed oil $33.96 \%$, corn oil $29.42 \%$ )

According to the results shown in Fig. 1, it was found that at the end of the selected oxidation period of the experimental sample of the blend, the acid and peroxide numbers were increased to $0.28 \mathrm{mgKOH} / \mathrm{h}$ and $1.9 \mathrm{mmol} 1 / 2 \mathrm{O} / \mathrm{kg}$, respectively, for the shelf life of 21 days.

6.2. The results of studies of the kinetics of oxidation of fat released from milk-containing curd paste. The results of the studies carried out on the change in the acid and peroxide values of the preliminarily isolated fat from the milk-containing curd paste are shown in Fig. 2.

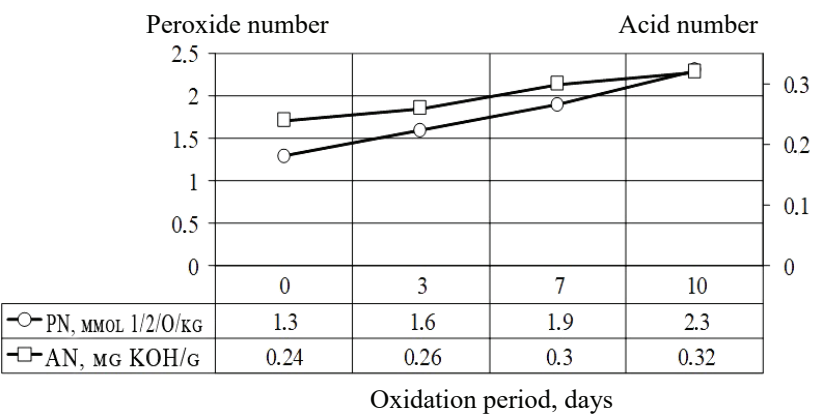

Fig. 2. Study of the kinetics of oxidation of milk-containing curd paste (shelf life 7 days)

In accordance with the obtained results of the kinetics of oxidation of the released fat of milk-containing curd paste, a slight increase in the acid and peroxide numbers is noted.

So, at the end of the 7-day warranty period, the indicators increased to $0.3 \mathrm{mgKOH} / \mathrm{h}$ and $1.9 \mathrm{mmol} 1 / 2 \mathrm{O} / \mathrm{kg}$, respectively. At the end of 10 days - up to $0.32 \mathrm{mgKOH} / \mathrm{h}$ and $2.3 \mathrm{mmol} 1 / 2 \mathrm{O} / \mathrm{kg}$, respectively.

6.3. The results of studies of the kinetics of oxidation of fat released from milk-containing sour cream sauce. The data of experimental studies of the dependence of the peroxide and acid numbers on the oxidation term are shown in Fig. 3.

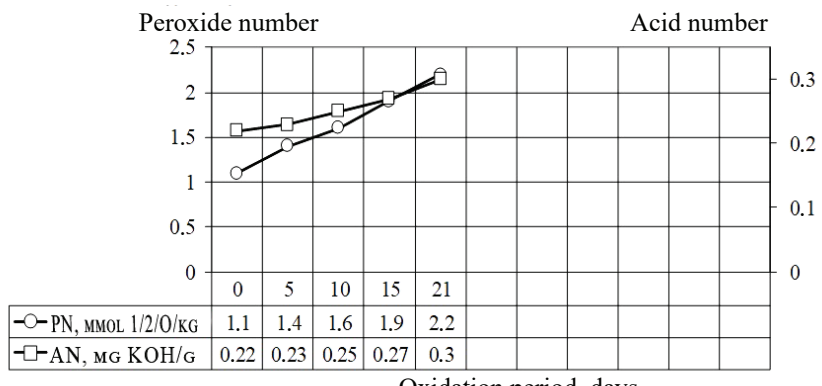

Oxidation period, days

Fig. 3. Study of the kinetics of axidation of milk-containing sour cream sauce (shelf life 14 days)

Based on the results of the kinetics of oxidation of the released fat from milk-containing sour cream sauce, shown in Fig. 3, there is a tendency for a gradual increase in acid and peroxide numbers with an increase in the oxidation time. It is noted that the maximum values of acidic $-0.3 \mathrm{mgKOH} / \mathrm{h}$ and peroxide values $-2.2 \mathrm{mmol} 1 / 2 \mathrm{O} / \mathrm{kg}$ at the end of the shelf life -21 days are reached.

6.4. The results of organoleptic studies of experimental samples of a blend of vegetable oils. Due to the fact that the addition of the developed blend of vegetable oils with the technology of milk-containing products can affect its final organoleptic characteristics, it was necessary to investigate the organoleptic characteristics of experimental blend samples for 21 days (Table 3).

From the analysis of the data obtained, it can be seen that organoleptic indicators did not undergo changes during 21 days of storage. At the end of storage, the taste and smell remained unsaturated with slightly perceptible notes of used oils. 


\begin{tabular}{|l|l|c|l|}
\multicolumn{5}{|c|}{ Trganoleptic characteristics of experimental samples } \\
of vegetable oils blend
\end{tabular}

6.5. The results of organoleptic studies of mixtures of vegetable and animal fats from milk-containing curd paste. The results of the organoleptic evaluation of the released fat from the milk-containing curd paste during storage are given in Table 4.

Organoleptic characteristics of the released fat from milk-containing curd paste

\begin{tabular}{|l|l|l|l|}
\hline \multirow{2}{*}{ Indicator } & \multicolumn{3}{|c|}{ Extracted fat from milk-containing curd paste } \\
\cline { 2 - 4 } & \multicolumn{1}{|c|}{ O day } & \multicolumn{1}{c|}{7 days } & \multicolumn{1}{c|}{10 days } \\
\hline \multirow{3}{*}{ Taste } & $\begin{array}{l}\text { Clean, pleasant, cha- } \\
\text { racteristic of milk } \\
\text { fat, light notes of } \\
\text { blend are hardly } \\
\text { perceptible, without } \\
\text { foreign tastes }\end{array}$ & $\begin{array}{l}\text { Inherent in milk fat, } \\
\text { slightly perceptible } \\
\text { notes of the intro- } \\
\text { duced blend, with- } \\
\text { out foreign tastes }\end{array}$ & $\begin{array}{l}\text { Inherent in milk fat, } \\
\text { light notes of blend } \\
\text { are hardly percep- } \\
\text { tible without for- } \\
\text { eign aftertastes }\end{array}$ \\
\hline Smell & $\begin{array}{l}\text { Weakly pronounced } \\
\text { aroma of a blend in } \\
\text { combination with a } \\
\text { rather pronounced } \\
\text { aroma characteris- } \\
\text { tic of milk fat }\end{array}$ & $\begin{array}{l}\text { Weakly pronounced } \\
\text { aroma of a blend in } \\
\text { combination with a a } \\
\text { rather pronounced } \\
\text { aroma characteris- } \\
\text { tic of milk fat }\end{array}$ & $\begin{array}{l}\text { An almost imper- } \\
\text { ceptible aroma of } \\
\text { a blend with subtle } \\
\text { hints of bitterness }\end{array}$ \\
\hline Colour & $\begin{array}{l}\text { Light yellow, uni- } \\
\text { form }\end{array}$ & $\begin{array}{l}\text { Light yellow, uni- } \\
\text { form }\end{array}$ & $\begin{array}{l}\text { Light yellow, uni- } \\
\text { form }\end{array}$ \\
\hline Transparency & $\begin{array}{l}\text { Transparent, with- } \\
\text { out sediment }\end{array}$ & $\begin{array}{l}\text { Transparent, with- } \\
\text { out sediment }\end{array}$ & $\begin{array}{l}\text { Transparent, with- } \\
\text { out sediment }\end{array}$ \\
\hline
\end{tabular}

From the analysis of the data obtained, given in Table 4, it can be seen that the organoleptic indicators did not undergo changes during 10 days of storage. At the end of the storage of the paste, the curd taste and smell remained milky with slightly perceptible notes of blend.

6.6. The results of organoleptic studies of mixtures of vegetable and animal fats from milk-containing sour cream sauce. The results of the organoleptic evaluation of the separated fat from the milk-containing sour cream sauce during storage are given in Table 5 .

Analyzing the data obtained in Table 5, let's observe that the organoleptic indicators did not undergo changes during 21 days of storage. At the end of the storage of the sour cream sauce, the taste and smell remained milky with hardly perceptible notes of bitterness aftertaste.
Organoleptic characteristics of the separated fat from milk-containing sour cream sauce

\begin{tabular}{|c|c|c|c|}
\hline \multirow{2}{*}{ Indicator } & \multicolumn{3}{|c|}{ Separated fat from milk-containing sour сгеam sauce } \\
\hline & 0 day & 14 days & 21 days \\
\hline Taste & $\begin{array}{l}\text { Clean, pleasant, cha- } \\
\text { racteristic of milk } \\
\text { fat, light notes of } \\
\text { blend are felt }\end{array}$ & $\begin{array}{l}\text { Inherent in milk fat, } \\
\text { light notes of blend } \\
\text { are felt }\end{array}$ & $\begin{array}{l}\text { Inherent in milk fat } \\
\text { with subtle after- } \\
\text { taste notes of bit- } \\
\text { terness }\end{array}$ \\
\hline Smell & $\begin{array}{l}\text { Weakly pronounced } \\
\text { aroma of a blend in } \\
\text { combination with a } \\
\text { rather pronounced } \\
\text { aroma characteris- } \\
\text { tic of milk fat }\end{array}$ & $\begin{array}{l}\text { Almost impercep- } \\
\text { tible aroma of a } \\
\text { blend, without for- } \\
\text { eign aftertastes }\end{array}$ & $\begin{array}{l}\text { Almost impercep- } \\
\text { tible aroma of a } \\
\text { blend with a subtle } \\
\text { off-flavor }\end{array}$ \\
\hline Colour & $\begin{array}{l}\text { Light yellow, uni- } \\
\text { form }\end{array}$ & Yellow, uniform & $\begin{array}{l}\text { Yellow, slightly dif- } \\
\text { ferent intensity }\end{array}$ \\
\hline Consistency & $\begin{array}{l}\text { Transparent, with- } \\
\text { out sediment }\end{array}$ & $\begin{array}{l}\text { Transparent, with- } \\
\text { out sediment }\end{array}$ & Slight turbidity \\
\hline
\end{tabular}

6.7. Discussion of research results. The obtained data on the kinetics of oxidation of a blend of vegetable oils are shown in Fig. 1 allow to conclude that the increase in the acid and peroxide numbers during the studied shelf life was not marked by intensity. The average threshold for the increase in PN and AN is insignificant and amounts to $0.02-0.03 \mathrm{mgKOH} / \mathrm{h}$ and $0.2-0.21 \mathrm{mmol} / 2 \mathrm{O} / \mathrm{kg}$ for 5 days. A slight increase in the concentration of free fatty acids, peroxides and hydroperoxides of the blend was noted, it can be argued:

- the presence of a significant amount of native an-

tioxidant substances and MUFAs in the used oils;

- compliance with storage conditions (at a temperature $t=+2 \ldots+6{ }^{\circ} \mathrm{C}$, without access to light and air).

In accordance with the studies carried out (Fig. 2, Fig. 3), there is a correlation dependence of the acid and peroxide numbers, due to their gradual increase during the entire storage period. The average threshold for an increase in PN and AN for experimental samples of fat isolated from milkcontaining curd paste and milk-containing sour cream sauce is $0.25-0.3 \mathrm{mgKOH} / \mathrm{h}$ and $0.3-0.35 \mathrm{mmol} / 2 \mathrm{O} / \mathrm{kg}$ (for 3 days) and $0.3 \mathrm{mgKOH} / \mathrm{h}$ and $0.2 \mathrm{mmol} 1 / 2 \mathrm{O} / \mathrm{kg}$ (for 5 days), respectively. The difference between the initial PN and AN data of experimental samples of fat mixtures is related to the titratable acidity of the products from which they were isolated.

According to the data presented in Fig. 2, 3, an abrupt increase in the amount of formation of free fatty acids and the formation of peroxides in the experimental samples of the mixture of fats is not observed. The delay in the intensity of their accumulation is due to the presence of native antioxidant substances in the blend. In particular, tocopherols $-\beta-, \gamma-$, $\delta$-tocopherol (found in large quantities in rapeseed oil), as well as the lack of action of the main activators of lipid oxidation. Such as an increase in the concentration of oxygen in oils, exposure to ultraviolet radiation, increased storage temperatures, etc.

According to the results obtained for the organoleptic evaluation of experimental samples of the blend and the released fat from milk-containing products, no significant changes were found during the studied shelf life. It should be noted that the undesirable bitter and herbaceous aftertastes typical of rapeseed oil in the composition of the test samples are absent. An almost complete depersonalization of the used vegetable oils is given, justified by the choice of product samples that have previously passed the technological stages of refining and deodorization. 


\section{SWOT analysis of research results}

Strengths. The experimentally confirmed possibility of using a blend of vegetable oils in the technologies of milk-containing products (milk-containing curd paste with sea buckthorn and milk-containing sour cream sauce with a mixture of garlic and green onions) can be considered a positive effect of the conducted scientific research. In addition, the obtained results of the kinetics of oxidation of a blend of vegetable oils allow it to be recommended as a substitute for milk fat, which does not require additional introduction of antioxidant substances.

Weaknesses. The conditions used for storing experimental samples and conducting research without fail provide for compliance with all specified technological parameters. However, in practice, in the production of food products, there is the possibility of a number of emergencies that were not taken into account when setting up experiments. That is, the actions of external factors provoked by the «human factor». In this regard, studies of the kinetics of the oxidation of the blend and the released fat from milk-containing products during autooxidation processes deserve attention. Namely: exposure to ultraviolet radiation, high temperature storage conditions for products, non-compliance with microbiological purity in production, etc.

Opportunities. The introduction of the results of scientific research into the technology of milk-containing products to provide both economic and social effects. For a manufacturer, the use of the developed blend of vegetable oils as a component of milk-containing products will minimize financial costs. The economic effect in this case will be achieved due to the absence of the need for additional introduction of antioxidants or other antioxidant substances. This is confirmed by the obtained results of indicators of acid and peroxide numbers, which are within the normal range during the shelf life of milk-containing products.

The social effect from the implementation of the research results will be achieved due to the possibility of expanding the assortment range of milk-containing products with functional properties.

It should be noted that due to the trend towards an increase in the relevance of a healthy lifestyle in the world community, functional products are gaining great demand. It is in the production of milk-containing products, due to its combination with plant raw materials, that a directed regulation of the constituent components is achieved. Thus, it becomes possible to provide the product with functional properties. However, the question arises of the influence of the introduction of vegetable fats on the kinetics of oxidation during the entire storage period and the need for additional introduction of synthetic antioxidant substances. In this regard, the obtained research results, which indicate the possibility of using a blend in the composition of milk-containing products without the addition of synthetic antioxidant substances, are promising for all countries of the world. After all, technologies for creating functional food products in the world provide for the absence of any synthetic components in their composition.

Based on the likelihood of unforeseen situations in production, studies that will assess the kinetics of the oxidation of the blend under the conditions indicated above are promising. In addition, the question of the timing at which the acid and peroxide values of the blend reach the maximum permissible values remains open. Their installation will make it possible to determine a number of functional food products in the technologies of which its use will be impractical.
In order to expand the spheres of application of the developed blend of vegetable oils, research aimed at proving the possibility of its use in technologies of oil and fat products is also promising.

Threats. To implement the implementation of the obtained research results at the enterprise, an item of additional costs will be associated with the purchase of an emulsifier (yolk) for creating emulsions, as well as subsequent pasteurization.

\section{Conclusions}

1. The dynamics of changes in acid and peroxide numbers of the developed blend based on natural vegetable oils and pre-isolated mixtures of vegetable and animal fats from milk-containing curd paste and milk-containing sour cream sauce has been investigated. The data obtained indicate that the increase in acid and peroxide values during the studied storage period does not differ in intensity. The average threshold for an increase in acid and peroxide numbers is insignificant and amounts to $0.02-0.03 \mathrm{mgKOH} / \mathrm{h}$ and $0.2-0.21 \mathrm{mmol} 1 / 2 \mathrm{O} / \mathrm{kg}$ for 5 days. In accordance with the obtained results of the kinetics of oxidation of the released fat of milk-containing curd paste, there is a slight increase in acid and peroxide numbers, namely: at the end of 7 days up to $0.3 \mathrm{mgKOH} / \mathrm{h}$ and $1.9 \mathrm{mmol} 1 / 2 \mathrm{O} / \mathrm{kg}$, respectively, and in at the end of 10 days - up to $0.32 \mathrm{mgKOH} / \mathrm{h}$ and $2.3 \mathrm{mmol} / 2 \mathrm{O} / \mathrm{kg}$. Based on the obtained results of the kinetics of oxidation of the released fat from the milk-containing sour cream sauce, there is a tendency to a gradual increase in the acid and peroxide numbers with an increase in the oxidation time. It is noted that the maximum values of acidic $0.3 \mathrm{mgKOH} / \mathrm{h}$ and peroxide values $-2.2 \mathrm{mmol} 1 / 2 \mathrm{O} / \mathrm{kg}$ at the end of the shelf life -21 days are reached.

2. Organoleptic studies of experimental samples of a blend of vegetable oils and isolated mixtures of vegetable and animal fats from milk-containing curd paste and milk-containing sour cream sauce were carried out. As a result, it was found that no significant changes were found during the studied storage period.

3. Based on the data obtained from studies of organoleptic indicators and the dynamics of changes in acid and peroxide numbers of selected experimental samples, the possible implementation periods were established: for milkcontaining curd paste -7 days, for milk-containing sour cream sauce - 14 days.

\section{Acknowledgement}

The research was carried out within the framework of research work $(R \& D)$ Implementation of resource-saving methods for modifying the functional and technological characteristics of milk whey in the technologies of food products for targeted purposes» (state registration number 0120U100868), Ukraine.

\section{References}

1. Ostrikov, A. N., Gorbatova, A. V., Filiptsov, P. V. (2016). Analiz zhirnokislotnogo sostava masel arakhisa i gretskogo orekha. Tekhnologii pischevoi i pererabatyvaiuschei promyshlennosti APKprodukty zdorovogo pitaniia, 4, 37-42.

2. Prokopenko, L. G., Boiniazheva, L. I., Pavlova, E. V. (2009) Polinenasyschennye zhirnye kisloty $\mathrm{v}$ rastitelnykh maslakh. Maslozhirovaia promyshlennost, 2, 11-12.

3. Safonova, E. F., Slivkin, A. I., Frolova, O. V., Korenskaia, I. M (2006). Izuchenie stabilnosti i srokov godnosti masla semian 
amaranta. Vestnik Voronezhskogo gosudarstvennogo universiteta. Seriia: Khimiia. Biologiia. Farmatsiia, 1, 213-215.

4. Belemets, T., Yushchenko, N., Lobok, A., Radzievskaya, I., Polonskaya, T. (2016). Optimization of composition of blend of natural vegetable oils for the production of milk-containing products. Eastern-European Journal of Enterprise Technologies, 5 (11 (83)), 4-9. doi: http://doi.org/10.15587/1729-4061.2016.81405

5. Martin-Moreno, J. M. (2000). The role of olive oil in lowering cancer risk: Is this real gold or simply pinchbeck? Journal of Epidemiology \& Community Health, 54 (10), 726-727. doi: http://doi.org/10.1136/jech.54.10.726

6. Radzievska, I. G., Melnyk, O. P. (2015). Kinetic Characteristics of Oil Natural Antioxidants. Nauka Ta Innovacii, 11 (4), 32-37. doi: http://doi.org/10.15407/scin11.04.032

7. Belemets, T., Yushchenko, N., Lobok, A., Radzievskaya, I., Polonskaya, T. (2016). Mathematical development program for calculation of fatty acid composition blend of vegetable oils. EUREKA: Life Sciences, 4, 57-66. doi: http://doi.org/10.21303/2504-5695.2016.00192

8. Belemets, T., Radzievskaya, I., Yushchenko, N., Kuzmyk, U. (2020). Determining the efficiency of using egg products for the stabilization of emulsion when making milk-containing curds-based products. Eastern-European Journal of Enterprise Technologies, 4 (11 (106)), 14-23. doi: http://doi.org/10.15587/1729-4061.2020.210006

9. Nogueira, M. S., Scolaro, B., Milne, G. L., Castro, I. A. (2019). Oxidation products from omega- 3 and omega- 6 fatty acids during a simulated shelf life of edible oils. $L W T, 101,113-122$ doi: http://doi.org/10.1016/j.lwt.2018.11.044

10. Özcan, M. M., Arslan, D. (2011). Antioxidant effect of essential oils of rosemary, clove and cinnamon on hazelnut and poppy oils. Food Chemistry, 129 (1), 171-174. doi: http:// doi.org /10.1016/j.foodchem.2011.01.055

11. Syrokhman, I. V. (2015). Problemy polipshennia spozhyvnykh vlastyvostei i stabilizatsii yakosti roslynnykh olii. Visnyk Lvivskoi komertsiinoi akademii. Seriia tovaroznavcha, 15, 71-76. Available at: http://nbuv.gov.ua/UJRN/Vlca_2015_15_15

12. Chakraborty, N., Muhie, S., Kumar, R., Gautam, A., Srinivasan, S. Sowe, B. et. al. (2017). Contributions of polyunsaturated fatty acids (PUFA) on cerebral neurobiology: an integrated omics approach with epigenomic focus. The Journal of Nutritional Biochemistry, 42, 84-94. doi: http://doi.org/10.1016/j.jnutbio.2016.12.006

13. Smoliar, V. I. (2008). Suchasni problemy yakosti kharchovykh zhyriv. Problemy kharchuvannia, 3/4, 5-12. Available at: http://medved. kiev.ua/web journals/arhiv/nutrition/2008/3-4 08/str05.pdf

14. Landucci, G., Pannocchia, G., Pelagagge, L., Nicolella, C. (2013). Analiz ta modeliuvannia protsesu pererobky promyslovoi roslynnoi olii. Zhurnal kharchovoi tekhniky, 116 (4), 840-851.

15. Szydłowska-Czerniak, A., Łaszewska, A. (2015). Effect of refining process on antioxidant capacity, total phenolics and prooxidants contents in rapeseed oils. LWT - Food Science and Technology, 64 (2), 853-859. doi: http://doi.org/10.1016/j.lwt.2015.06.069

16. Seppanen, C. M., Csallany, A. S. (2006). The effect of intermittent and continuous heating of soybean oil at frying temperature on the formation of 4-hydroxy-2-trans-nonenal and other $\alpha$-, $\beta$-unsaturated hydroxyaldehydes. Journal of the American Oil Chemists' Society, 83 (2), 121-127. doi: http:// doi.org/10.1007/s11746-006-1184-0

17. Bondarenko, Zh. V., Emello, G. G., Khavanskaia, O. I. (2016) Vliianie termoobrabotki na ustoichivost k okisleniiu i zhirnokislotnii sostav smesi rastitelnykh masel. Trudy BGTU. Seriia 2 Khimicheskie tekhnologii, biotekhnologiia, geoekologiia, 4, 162-166.

18. Matskiv, O. O., Solod, M. I., Vasylkevych, V. O., Ivasiv, V. V. (2015). Vyvchennia osnovnykh pokaznykiv yakosti sumishi llianoi, konoplianoi ta hirchychnoi olii dlia zastosuvannia yikh u kharchuvanni. Kharchova promyslovist, 18, 32-37. Available at: http://nbuv.gov.ua/UJRN/Khp_2015_18_8

19. Verhé, R., Verleyen, T., Van Hoed, V., De Greyt, W. (2006) Influence of refining of vegetable oils on minor components. Journal of Oil Palm Research, 4, 168-179.

20. Caponio, F., Pasqualone, A., Catalano, P., Gomes, T., Summo, C. (2004). Influenza della temperatura iniziale del frangitore sulfa qualità degli oli extra vergini di oliva estratti. Rivista Italiana delle Sostanze Grasse, 81 (1), 19-22.

21. Boriaev, G. I., Pogosian, D. G. (2008). Ispolzovanie selenopirana $\mathrm{v}$ kachestve antioksidanta $\mathrm{v}$ maslozhirovykh produktakh. Tekhnologiia pererabotki selskokhoziaistvennoi produktsii, 2, 76-79.

22. Shemanska, Ye. I. (2012). Sklad i biolohichna tsinnist olii kholodnoho presuvannia. Visnyk DonNUET. Ser. Tekhnichni nauky, 1 (53), 221-225.
23. Frenoux, J.-M. R., Prost, E. D., Belleville, J. L., Prost, J. L. (2001). A Polyunsaturated Fatty Acid Diet Lowers Blood Pressure and Improves Antioxidant Status in Spontaneously Hypertensive Rats. The Journal of Nutrition, 131 (1), 39-45. doi: http://doi.org/10.1093/jn/131.1.39

24. Leong, X. F., Ng, C. Y., Jaarin, K., Mustafa, M. R. (2015). Effects of repeated heating of cooking oils on antioxidant content and endothelial function. Austin Journal of Pharmacology and Therapeutics, 3 (2), 1068.

25. Falade, A., Oboh, G., Okoh, A. (2017). Potential Health Implications of the Consumption of Thermally-Oxidized Cooking Oils - a Review. Polish Journal of Food and Nutrition Sciences, 67 (2), 95-105. doi: http://doi.org/10.1515/pjfns-2016-0028

26. Khatskevych, Yu. M., Nepochatykh, T. A., Ivanchenko, O. S. (2011). Zminy yakosti zhyrovykh komponentiv u maioneznii produktsii pid chas zberihannia. Prohresyoni tekhnika ta tekhnolohii kharchooykh vyrobnytsto restorannoho hospodarstva $i$ torhivli, 1 , 282-287. Available at: http://nbuv.gov.ua/UJRN/Pt 2011147

27. Efimenko, S. G., Efimenko, S. K., Bykova, S. F., Davidenko, E. K. (2012). Novye vidy podsolnechnogo masla s izmenennym zhirnokislotnym sostavom. Maslozhirovaia promyshlennost, 4, 16-18.

28. Nekrasova, T. E. (2005). Naturalnye antioksidanty dlia maslozhirovoi produktsii. Masla $i$ zhiry, 4, 2-3.

29. Aluyor, E. O., Ori-Jesu, M. (2008). The use of antioxidants in vegetable oils - A review. African Journal of Biotechnology, 7 (25), 4837-4842. Available at: http://www.ajol.info/index. php/ajb/article/view/59677

30. Fedak, N. V., Dykhtiar, A. M., Kyrychenko, V. V., Tymchuk, S. M., Pozdniakov, V. V., Tymchuk, V. M. (2012). Dynamika vmistu tokoferoliv v oliiakh soniashnyku z riznym zhyrnokyslotnym skladom v protsesi nahrivannia. Pratsi Tavriiskoho derzhavnoho ahrotekhnolohichnoho universytetu, 12 (4), 139-145.

31. Paronian, V. Kh., Voskanian, O. S. (2004). Analiz vliianiia razlichnykh faktorov na kachestvo zhirov. Maslozhirovaia promyshlennost, 2, 10-11.

32. Karabulut, I. (2010). Effects of $\alpha$-tocopherol, $\beta$-carotene and ascorbyl palmitate on oxidative stability of butter oil triacylglycerols. Food Chemistry, 123 (3), 622-627. doi: http:// doi.org/10.1016/j.foodchem.2010.04.080

33. Palamarchuk, A. I., Lashko, N. P. (2015). Vplyv antyoksydantnykh vlastyvostei vitaminu $\mathrm{E}$ na termin zberihannia roslynnoi olii. Aktualni pytannia biolohii, ekolohii ta khimii, 10 (2), 83-90. Available at: http://nbuv.gov.ua/UJRN/apd_2015_10_2_11

34. Pasichnyi, V., Shevchenko, O., Khrapachov, O., Marynin, A., Radzievskaya, I., Matsuk, Y. et. al. (2020). Prognostication of storage terms for pasteurized sausages with active package elements. EUREKA: Life Sciences, 4, 34-43. doi: http://doi.org/ 10.21303/2504-5695.2020.001376

Tatiana Belemets, Assistant, Department of Biotechnology and Microbiology, National University of Food Technologies, Kyiv, Ukraine,e-mail: Tatiana_Belemets@i.ua, ORCID: http://orcid.org/ 0000-0002-6701-1711

Irina Radzievskaya, PhD, Associate Professor, Department of Technology of Fats and Perfumery-Cosmetic Products, National University of Food Technologies, Kyiv, Ukraine, e-mail: logos2007@ukr.net, ORCID: http://orcid.org/0000-0002-6081-0625

Oksana Tochkova, PhD, Associate Professor, Department of Technology Conservation, National University of Food Technologies, Kyiv, Ukraine, e-mail: oksanatochkova063@gmail.com, ORCID: http:// orcid.org/0000-0002-0315-8757

Nataliia Yushchenko, PhD, Associate Professor, Department of Restaurant Technology and Ayurvedic Products, National University of Food Technologies, Kyiv, Ukraine, e-mail: YuNM_NUFT@ukr.net, ORCID: http://orcid.org/0000-0002-4277-5782

Uliana Kuzmyk, PhD, Associate Professor, Department of Milk and Dairy Product Technology, National University of Food Technologies, Kyiv, Ukraine, e-mail: ukuzmik@gmail.com, ORCID: http://orcid.org/ 0000-0003-2617-006X

Artur Mykhalevych, Department of Milk and Dairy Product Technology, National University of Food Technologies, Kyiv, Ukraine, e-mail: artur0707@ukr.net, ORCID: http://orcid.org/0000-0002-4212-9457 